\title{
THE ABUNDANCE OF OCTOPUS IN THE ENGLISH CHANNEL
}

\author{
By W. J. Rees and J. R. Lumby \\ (Text-figs. I-5)
}

During 1950, the Common Octopus (Octopus vulgaris Lamarck) was to be found along the south coast of England in greater numbers than at any time since Garstang (1900) reported on the 'plague' on the coasts of Devon and Cornwall in $1899-1900$.

In earlier papers (Rees, 1950, 1952) the distribution of the octopus in our northern waters was reviewed, and it was demonstrated that this species is an immigrant which breeds on our south coast only rarely. It reaches these coasts by being brought there as a planktonic larva by the water circulation in the English Channel and by migrations of the adult. The most important factor in controlling the movements of the adult, however, might be expected to be the water temperature in the English Channel-where the species is at the northern limit of its breeding range and might therefore be extremely sensitive to slight changes in temperature.

The earlier paper (1950) was completed in January of that year, at a time when fishermen in the Channel Islands were complaining of the abundance of octopus in their area. It then seemed likely (a surmise which proved correct) that the octopus might also be more abundant on the English coast in the summer, if events followed the same course as in 1899-1900. This paper deals primarily with its abundance in 1950 and subsequently. It is now possible to present a much better picture of the distribution of larvae based on the pilchard-egg investigations of the Ministry of Agriculture and Fisheries. More information is also available on water temperature as a controlling factor, and the possible seasonal migration of the adult in normal and abnormal years is considered.

\section{The Abundance of the Adult}

Early in I950 there was no evidence that Octopus would be abundant on the English coast, but the presence of the species in numbers in the Channel Islands in January was an indication that a repetition of the events of I899I900 was a distinct possibility. In March I950, however, an occasional juvenile Octopus was caught by the research vessels of the Marine Biological Association off Plymouth. One of these, a specimen with an arm span of $70 \mathrm{~mm}$ and a ventral mantle length of $\mathrm{I} 4 \mathrm{~mm}$, was kindly sent to us by 
Mr F. S. Russell. These can be assumed to have been spawned in the previous July or August and to be about 7-8 months old.

Apart from juveniles, the first indication of real abundance came from the Devon area. The trawler Girl Vine (Skipper T. Harvey), working out of Torquay in the third week of May in a position 20 miles S.S.E. of Berry Head, reported that in one haul the cod-end of the trawl was full of Octopus. These were large with a span of about $3 \mathrm{ft}$. A few octopus were also taken in other hauls made during the same fishing trip. Fourteen days later on the same grounds octopus were not noticeably abundant; later events proved that they had moved inshore.

During the last week in May an octopus with an arm span of about 30 in. was taken in a crab pot at Bexhill by a fisherman ( $\mathrm{Mr} \mathrm{J}$. Easton). In the first half of June octopus began taking lobsters and crabs from baited pots in Start Bay and Babbacombe. As the season advanced Babbacombe fishermen were taking 30-40 a day in their pots. At Beer and Seaton, the shell-fishery was almost abandoned for the same reason. The area between Seaton and Brixham appears to have been affected the most, but farther west some Plymouth fishermen abandoned shell-fishing because the octopus were taking their catches. For the first time in many years the Plymouth Laboratory was able to obtain octopus in sufficient numbers for experimental work.

During August a large number of octopus entered Dartmouth Harbour. Most of these were large with an arm-span of $4 \mathrm{ft}$.; some were caught by hook and line. Fishermen reported seeing young octopus of very small size during the autumn in the south Devon area.

On the north coast of Devon Octopus were not noticeably abundant, but a few were caught off Lundy Island. Towards the middle of October few octopus were being caught on the south Devon coast.

On other parts of the south coast of England Octopus was also common. In mid-August specimens $2 \frac{1}{2}-3 \mathrm{ft}$. in arm-span were being caught in some numbers by anglers at Eastbourne and Brighton, and during the first week of September octopus of all sizes up to $4 \mathrm{ft}$. 6 in. in arm-span were being caught in lobster pots on Hoo Bank off Selsey Bill. There was an interesting record of an octopus ( $30 \mathrm{in}$. in arm-span) from Deal on 2 September; this specimen, now in the British Museum (Natural History), is one of the few ever recorded from the North Sea.

Octopus were being caught throughout the winter (I950-5I) by the R.V. Sabella operating within I6 miles of Plymouth Breakwater (see Appendix I by Lieut.-Commander C. A. Hoodless, D.S.C., R.N.R.). It is interesting to note that this ship caught its first octopus on 4 September I950, the totals for September, October, and November being 2, 3 and 2. These small numbers probably give an accurate impression of the situation on offshore grounds and serve to emphasize that the main body of octopus was close inshore. One Plymouth fisherman, who had seen only four octopus in 35 years of fishing, 
caught no fewer than fifty in and on his lobster pots by the first week in October. The increase in catches in winter and spring suggests that the octopus, like Eledone, moves into deeper water after the summer.

In Jersey, too, the octopus was numerous in 1950, and there appears to have been no reduction in numbers in $195 \mathrm{I}$ and in 1952 . On the French coast also, during the summer of 1950, Octopus appears to have been very abundant both in the neighbourhood of Cherbourg and on the north coast of Brittany.

Prof. J. Z. Young, F.R.S., has kindly allowed us to publish some notes on the situation in the Cherbourg area in September I950. He states: "There were considerable signs of a plague, at least on the stretch from Cherbourg to the tip of the Hague peninsula. On 4 September I saw a great many of them lying about in the port at Cherbourg; they were being caught by boys and were apparently unsaleable, the fishermen were baiting their lines with pieces of tentacle. On I I September I was still more struck with their abundance at Omonville. There is a little harbour there and the jetty runs out among the rocks. Looking down among these we could see a great number of Octopus moving about in the water at high tide. For instance, at one moment we counted no less than twenty-five in sight, even though the sea was rough and vision was limited to a few yards. Of course I cannot say whether they would be equally abundant away from the jetty, perhaps they had come in for food. They were certainly very hungry and attacked pieces of dead octopus as soon as lowered into the water; in fact the boys were fishing for them in this way and once the dead octopus had been seized the live ones would hang on to it and could be drawn out of the water on to the jetty. In this way one could pull them out one after the other almost as fast as the bait could be lowered into the water.

'Elsewhere along the coast there were signs of abundance though I did not actually see such large numbers anywhere else. However at low water they were caught by prodding under rocks at Urville on several days.'

Some additional information published in La Pêche Maritime, Nos. 868, 869 and 870 (1950) is quoted below:

May I950: Portsall. 'La pêche aux crustacés (homards et langoustes) a été d'un rendement à peu près nul et d'ailleurs la côte à un tel point infestée de pieuvres qu'il devient difficile de preserver le crustacé dans les casiers et viviers où ces mollusques parviennent toujours à s'infiltrer.'

Fuly I950. 'Les pieuvres très nombreuses, certaines d'assez grandes dimensions, pénétrant jusque dans les concessions ostréicoles, font des sensibles ravages. Les baies ont été visitées par de nombreux crabes-araignées d'un calibre respectable, mais se déplaçant rapidement, au grand dam des pêcheurs.'

August 1950: Paimpol. 'Les pieuvres sont plus nombreuses que jamais; on les trouve même dans les concessions ostréicoles. Les crabes-araignées 
ont été parfois abondants dans les baies, se déplaçant jusque dans les chenaux.'

It is thus evident that the octopus was even more abundant in 1950 on the French coast than on the English side.

\section{Planktonic LaRvae In I948, I949 AND I950}

In an earlier report the Channel larvae from cruises in I948 and I949 were plotted on a single chart (Rees, I950, fig. 2). The results for these two years have been re-plotted on separate charts, and results from the pilchard-egg cruises of the Ministry of Agriculture and Fisheries research vessel Sir Lancelot have been added for 1949. The results for I950 are based almost entirely on the catches of the Sir Lancelot.

The year I948. In this year only the collections made by the M.Y. Manihine in the eastern Channel and over the eastern end of the Hurd Deep were available (Fig. I, I948). Young larvae found at five stations at the end of August are noted in Table I.

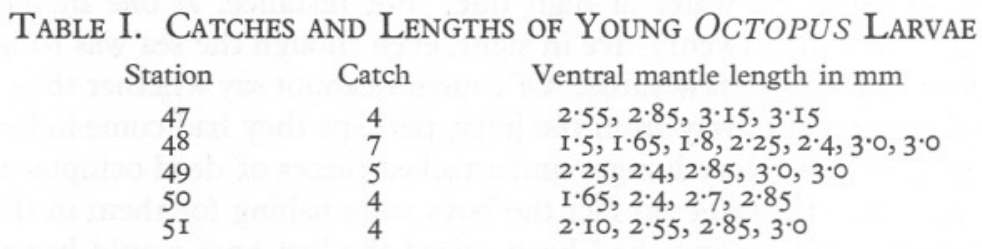

The positions of these stations have already been given (Rees, I950, p. 368). There was no information on distribution to the west and no larvae were taken at St. 45 (the southernmost of a line running across the Channel from south of the Isle of Wight towards the Cherbourg peninsula). Two larvae at St. 48 and another at St. 50 were at or just about hatching size; they could not have been many days old, ${ }^{1}$ and it could be inferred that the breeding grounds were not far away.

The year 1949. During this year plankton hauls were again taken in the central area of the Channel by the Manihine in August and Octopus larvae obtained both to the east and the west of the previous positions (Rees, I950, p. 368). However, a much more complete picture of distribution during June and September was made possible by an examination of the plankton hauls taken by the Sir Lancelot. These cruises covered the whole of the Channel and, although intended for another purpose, yielded valuable information on where larvae could be found during these particular months (Fig. I, I949). Larvae were found at three Sir Lancelot stations (39, 45 and 46) in June off the north coast of Brittany. No records are available for July and only those

${ }^{1}$ It is assumed here that larvae would hatch at about $\mathrm{I} \cdot 5 \mathrm{~mm}$ (in ventral mantle length) as at Naples. 
of the Manihine for August. The apparent absence of larvae in the central Channel to the north of Alderney is thus due to absence of records. The September cruise of the Sir Lancelot yielded larvae at five stations; all were farther away from the breeding grounds, on the north coast of France and the Channel Islands, than recorded earlier in the year, and must be presumed to have been dispersed by water movements. Larvae at two stations near the English coast appear to be sufficiently far north to settle down on offshore grounds and to work their way inshore during the following year.

The year 1950. The pilchard-egg cruises of the Sir Lancelot were continued during April, May, June, July and August. No Octopus larvae were found in April and May, but in June two larvae were obtained at a station to the north of Roscoff. The July cruise yielded the only distribution picture we have for this month, and it is significant that all the larvae (except those at the two easternmost stations) were found fairly close to the Channel Islands and the Cherbourg Peninsula (Fig. I, I950). It is reasonable to assume that the larvae at Sts. 33 and 34 in mid-Channel were being transported fairly rapidly in an easterly direction. The series of night hauls at St. $\theta$ revealed the presence of larvae in no fewer than fourteen hauls (the maximum catch being seven and the minimum one), from which we can infer that larvae were by no means rare and that hatching from the eggs was in full swing. From the size of the larvae it can be assumed that they had been hatched at the end of June and the beginning of July; but most of them were small and probably not more than 7-I4 days old.

In August (as shown separately in Fig. I) larvae were found at all but three of the stations worked on the south side of the Channel from Ushant to approximately $\mathrm{I}^{\circ} \mathrm{W}$. There was also an isolated larva at St. I5 off the Cornish coast which presents an intriguing problem, whether it was carried across the Channel from the region of Ushant by the current or whether it was spawned locally (but see p. 522). This picture for August indicates that larvae were widely spread during this year, but unfortunately there are no records suitable for comparison, so that we do not know whether this is the normal pattern of distribution for this month or whether it is only an indication of widespread successful hatching of larvae associated with the plague years of 1949-50. These are the last detailed records available to us.

The records indicate that hatching begins in June on the north coast of Brittany and by July larvae are more common in the mid-Channel area and around the Channel Islands. In August (if we are to judge by the years for which we have records) larvae are more abundant and more widespread than during earlier months, while in September fewer larvae are planktonic and they are farther north and east in distribution than in any other month.

A comparison of relative abundance of larvae during these years, especially as I950 was a 'plague' year, would have been of great interest. However, there were no Sir Lancelot cruises for July 1949 (to compare with July I950), 


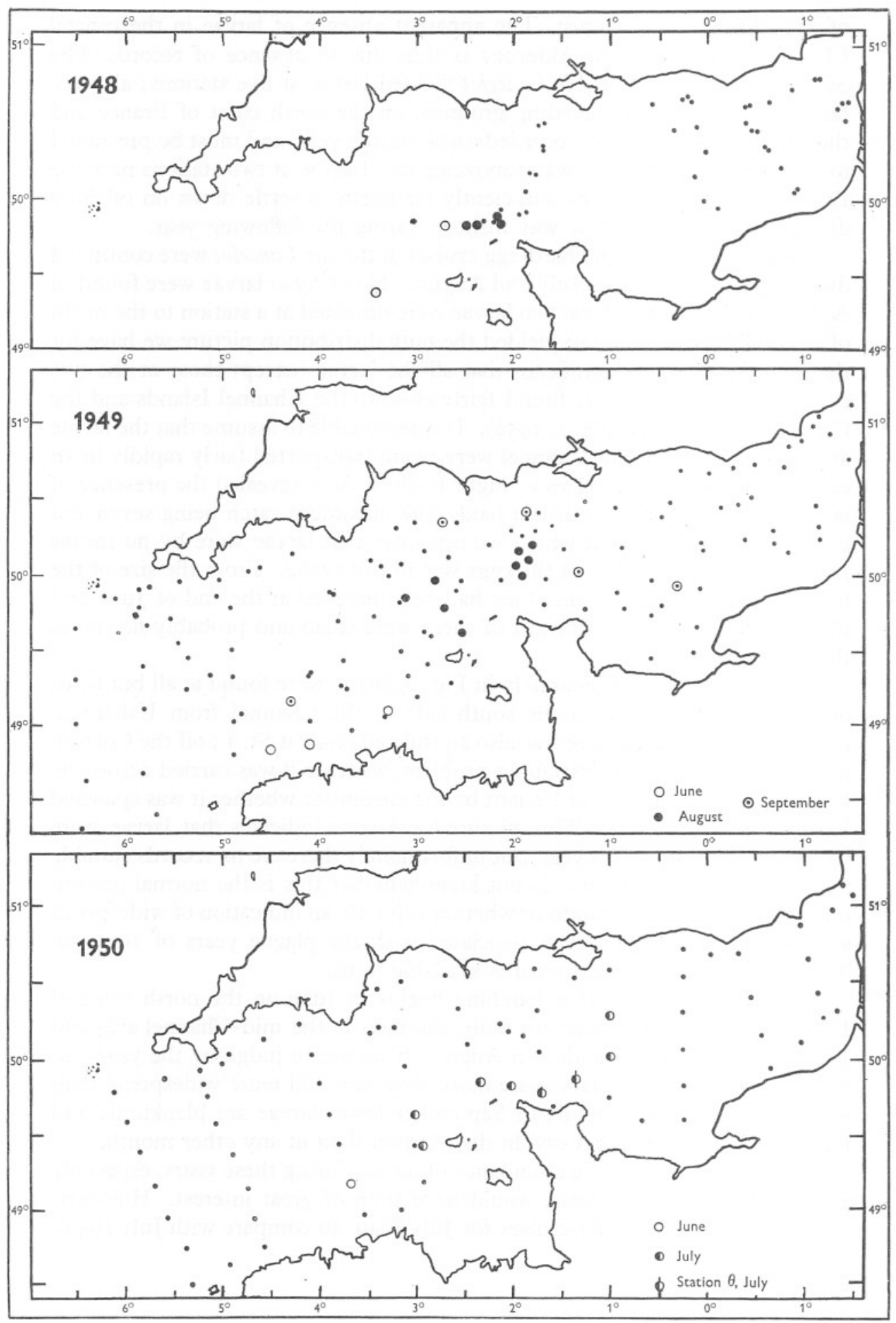



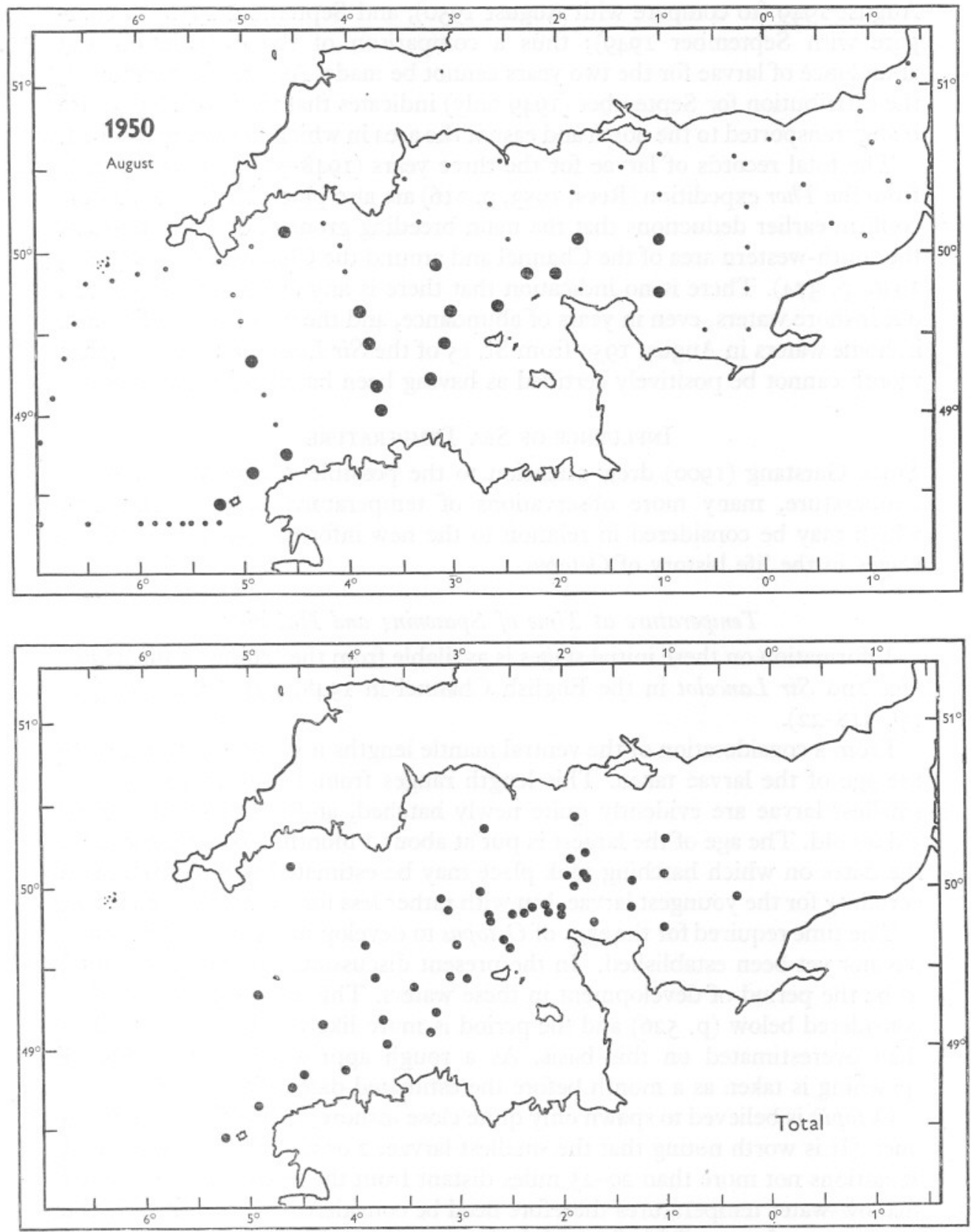

Fig. I. The distribution of Octopus larvae 1948-50. Stations worked during the period in question are marked with a dot. Circles denote stations at which larvae were taken, as specified on the separate maps. The two open circles on the I 948 map denote positions at which the Danish research vessel Thor took larvae in I906 and I9I0. These positions are also included in the last map which gives an aggregate of positions at which larvae were taken. 
August I949 (to compare with August I950), and September I950 (to compare with September 1949); thus a comparison of the distribution and abundance of larvae for the two years cannot be made. As already mentioned, the distribution for September (I949 only) indicates that these late larvae are being transported to the north and east of the area in which they were hatched.

The total records of larvae for the three years (I948-50) and two records from the Thor expedition (Rees, I953, p. 216) are also plotted in Fig. I). These confirm earlier deductions that the main breeding grounds of Octopus are in the south-western area of the Channel and around the Channel Islands (Rees, I950, p. 374). There is no indication that there is any extensive breeding in our inshore waters, even in years of abundance, and the only record of a larva in home waters in August I950 from St. I5 of the Sir Lancelot's cruise in that month cannot be positively certified as having been hatched in that area.

\section{INFLUENCE OF SeA Temperature}

Since Garstang (1900) drew attention to the possible role played by water temperature, many more observations of temperature have accumulated, which may be considered in relation to the new information on the various stages in the life history of Octopus.

\section{Temperature at Time of Spawning and Hatching}

Information on these initial stages is available from the cruises of the Manihine and Sir Lancelot in the English Channel in I948, I949 and I950 (see pp. 518-22).

From a consideration of the ventral mantle lengths it is possible to estimate the age of the larvae taken. This length ranges from $\mathrm{I} \cdot 5$ to $6 \mathrm{~mm}$, and the smallest larvae are evidently quite newly hatched, and not more than 2 or 3 days old. The age of the largest is put at about 2 months. From these data, the dates on which hatching took place may be estimated with considerable certainty for the youngest larvae, but with rather less for the larger specimens.

The time required for the eggs of Octopus to develop in the English Channel has not yet been established. In the present discussion a month is assumed to be the period of development in these waters. This assumption is further considered below (p. 526) and the period is more likely to have been underthan overestimated on this basis. As a rough approximation the date of spawning is taken as a month before the estimated date of hatching.

Octopus is believed to spawn only quite close inshore, within the Io $\mathrm{m}$ depth line. (It is worth noting that the smallest larvae, 2 or 3 days old, were found at stations not more than 20-25 miles distant from the nearest coasts.) Only shallow-water temperatures therefore need be considered. Unfortunately the temperature data available for such inshore waters, particularly on the French side, are decidedly meagre. We are indebted to $\mathrm{Mr} \mathrm{H}$. J. Baal, President of the Société Jersiaise, for a series of monthly average temperatures at Jersey. 
These are based on observations made at 9 a.m. daily at I $\mathrm{m}$ depth in the shade at the end of the Albert Pier, St Helier. For the western part of the Brittany coast, the only data available consist of the surface observations made near Ushant by commercial vessels crossing the mouth of the Channel, between Ushant and Land's End. The position to which the data used relate is approximately $48^{\circ} 27^{\prime} \mathrm{N}$., $5^{\circ} \mathrm{I} 5^{\prime} \mathrm{W}$., admittedly some distance off the mainland. In addition, there are the routine observations made by the commercial vessels on the Southampton-Channel Islands service, and by the research vessels of the Marine Biological Association off Plymouth. Except those for Jersey, these data are published in the Bulletins Hydrographiques issued by the International Council for the Exploration of the Sea, Copenhagen. They are illustrated, together with those for Jersey, for the relevant period, in Fig. 2.

The use of surface temperatures is justified in present circumstances, since at least in April and the early part of May, the waters of the English Channel may be expected to be homothermal (see Dietrich, I950). Surface observations are thus reasonably reliable guides to the conditions on the sea bottom at this season, especially in the shallow waters inshore. Certain disadvantages may arise, however, from the fact that most of the data employed for this inquiry are in the form of monthly averages. In shallow water, the fluctuations of temperature are likely to be much greater than in the deeper water well clear of the land. It can be seen, for example, in Fig. 2 that the annual range tends to be considerably greater at Jersey than off Ushant, or even off Plymouth. Short-period fluctuations, on the other hand, are not to be discerned in the curves based on monthly averages. One or two very cold days in an otherwise mild month may have a disproportionately adverse effect on biological processes, while a few bursts of sunshine in an otherwise gloomy month may give a lot of encouragement to them. Such effects are likely to be masked by the use of monthly averages. However, other uncertainties involved in, for example, the dates of spawning and hatching and the places at which they occurred, are so numerous that it is doubtful whether we could profit by a closer examination of the temperature conditions.

During the greater part, if not all, of the season in which spawning, development, and hatching are taking place, the water temperature is in general rising. By estimating the dates, in the way described, on which the largest, and therefore the oldest, larvae taken were hatched and spawned, and reading the temperatures for these dates from the appropriate curves, we arrive at an estimate of the lowest water temperatures at which these events occurred. The values so obtained are shown in Table II.

The table indicates that in the years 1949 and 1950 spawning began in the first half of May on the western part of the Brittany coast, and in the latter half of the month in the Channel Islands district. For 1950, these dates are further supported by the fact that larvae were absent from the catches in 


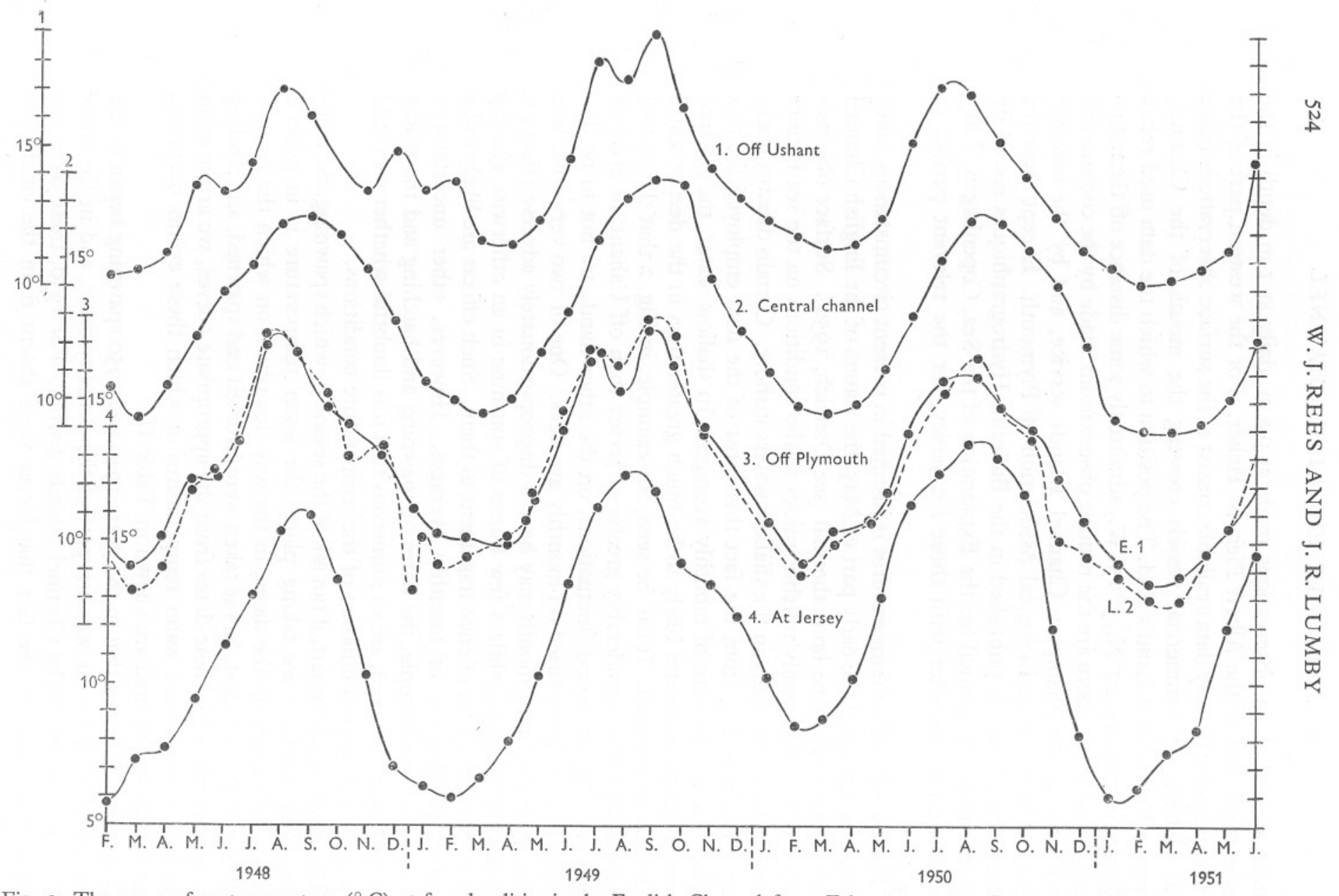

Fig. 2. The sea surface temperature $\left({ }^{\circ} \mathrm{C}\right)$ at four localities in the English Channel from February I948 to June I95I. The curves shown for the two positions off Plymouth are based on single observations; the other three curves are based on monthly mean values. The locality off Ushant (I) is Region Io (see Lumby, I935); the Central Channel (2) is a combination of Regions 20, 24 and 25; the observations off Plymouth (3) were made at St. L.2, close to the Breakwater, and at St. E. I, close to the Eddystone; for Jersey (4) the observations were taken off the Albert Pier, St Helier. 
April and May that year, and first appeared in June. The water temperature at first spawning is found to be about $\operatorname{II} \frac{1}{2}^{\circ}$ or $\operatorname{I2}{ }^{\circ} \mathrm{C}$.

Table II. The Estimated Dates and Presumed Localities of Spawning and Hatching, with the Appropriate Surface Water Temperatures $\left({ }^{\circ} \mathrm{C}\right)$

\begin{tabular}{|c|c|c|c|c|c|c|c|}
\hline & & & Spawning & & & tching & \\
\hline$\underset{(\mathrm{I})}{\text { Cruise }}$ & $\begin{array}{l}\text { Locality } \\
\text { (2) }\end{array}$ & $\begin{array}{l}\text { Date } \\
(3)\end{array}$ & $\begin{array}{c}T^{\circ} \mathrm{C} \\
(4)\end{array}$ & & $\begin{array}{l}\text { Date } \\
(5)\end{array}$ & $\begin{array}{l}T^{\circ} \mathrm{C} \\
(6)\end{array}$ & \\
\hline M., Aug. I948 & C.I. & 7 July & I2.6 (J.) & $12 \frac{1}{2}$ & 7 Aug. & I $4.8(\mathrm{~J})$. & I5 \\
\hline S.L., June I949 & B. & I8 May & $\left.\begin{array}{l}\text { I0.5 (J.) } \\
\text { I2.5 (U.) } \\
\text { I I.8 (C.) }\end{array}\right\}$ & $\operatorname{II} \frac{1}{2}$ & I8 June & $\left.\begin{array}{l}\text { I3.7 (J.) } \\
\text { I } 4.8 \text { (U.) } \\
\text { I3.4 (C.) }\end{array}\right\}$ & I4 \\
\hline M., Aug. I949 & C.I. & I June & $\mathrm{I} 2 \cdot 0(\mathrm{~J})$. & 12 & I July & I5.O (J.) & $\mathbf{I}_{5}$ \\
\hline S.L., Sept. I949 & B. \& C.I. & 7 July & $\begin{array}{l}\text { 15.5 (J.) } \\
\text { 17.3 (U.) (C.) }\}\end{array}$ & r6 & 7 Aug. & $\left.\begin{array}{l}17 \cdot 2 \text { (J.) } \\
\text { I7·3 (U.) }\end{array}\right\}$ & I7 \\
\hline S.L., June I950 & B. & 5 May & $\begin{array}{l}\text { I2 } 2 \text { (J.) } \\
\text { I2 } 2 \cdot \mathrm{I} \text { (U.) }\end{array}$ & 12 & 5 June & $\left.\begin{array}{l}\text { I5.8 (J.) } \\
\text { I } 4.2 \text { (U.) }\end{array}\right\}$ & $\mathbf{I}_{5}$ \\
\hline S.L., July I950 & C.I. & 22 May & I3.6 (J.) & $13 \frac{1}{2}$ & 22 June & I6.7 (J.) & It \\
\hline S.L., Aug. I950 & B. \& C.I. & I2 June & $\begin{array}{l}\text { I6.6 (J.) } \\
\text { I5.I (U.) }\}\end{array}$ & I6 & I2 July & $\left.\begin{array}{l}\text { I7.5 (J.) } \\
\text { I7. I (U.) }\end{array}\right\}$ & 17 \\
\hline
\end{tabular}

In column I, M. indicates Manihine; S.L., Sir Lancelot. In column 2, C.I. indicates the Channel Islands region; B., the western part of the north coast of Brittany. In columns 4 and 6, J. indicates at Jersey; U., off Ushant; and C., the central Channel between the Isle of Wight and the Cotentin peninsula. The temperatures in heavy type are the round values considered acceptable. Spawning and hatching refer to the oldest larvae taken on each cruise.

\section{Effect of Temperature on Date of Spawning}

As regards the effect of temperature on the time when spawning begins, the possibility must not be overlooked that Octopus may start to spawn in the English Channel some time in May, mainly in response to an innate rhythm, with only very little regard to water temperature. The average temperature both at Jersey (for the years 1935-39, I946-52) and also off Ushant (for the years $1928-5 \mathrm{I}$ ) reaches $\mathrm{II} \frac{1}{2}^{\circ} \mathrm{C}$ at about the end of the first week in May. In separate years this value may be reached at Jersey as early as mid-April (e.g. 1933) or may not occur until mid-June (1948). If spawning is closely controlled by temperature, fluctuations of a similar order of magnitude must be expected in the dates on which the process starts. It is true that the results of the August cruise in 1948, a year with particularly low spring temperatures at Jersey, point in this direction, as they give a date for first spawning as late as July. But as the table shows, in 1949 and 1950 , when there were sequences of cruises, the later the cruise, the later is the estimated date of first spawning. The explanation of this is not apparent, unless it be that by the time of the later cruises, the largest larvae may have already been so close to the bottom that they were not taken by the Sir Lancelot's nets. ${ }^{1}$

1 The Manihine made horizontal hauls as close to the bottom as practicable, whereas the Sir Lancelot's were vertical hauls. 
There is, however, another feature which suggests that spawning began later in 1948 than in 1949 or 1950 , namely, that the distribution of the larvae in August 1948 was not quite so wide as in the same month in the other two years. But not much reliance can be placed on this, since the western half of the Channel was not sampled in 1948. For the same reason it is doubtful whether we may conclude that the eggs spawned and larvae hatched in 1948 were fewer than in 1949 or 1950, as might at first sight appear to be the case. Moreover, these numbers may depend less upon temperature than upon the numbers of adults present. Thus the evidence at present available does not permit a decision to be reached on the question whether spawning may be expected to be earlier or later, or more or less intense, according as the water temperature is higher or lower.

Off Plymouth, the temperature of $\mathrm{II}_{\frac{2}{2}}{ }^{\circ} \mathrm{C}$ is reached on the average (1928-5I) only some 2 weeks later than on the French coasts. If Octopus can tolerate as wide a variation in the date of commencement of spawning as 2 months, it is surprising that it spawns so very rarely on the English coast. This suggests that in regard to choice of spawning ground some factor other than temperature determines the animal's preference for the southern side of the Channel over the northern.

\section{Accumulated Temperature and Development of the Egg}

In the foregoing discussion, the assumption is made that hatching occurs I month after spawning. No direct confirmation of this, however, is obtainable from the evidence at hand. In so far as 'accumulated temperature' (Tait, I95I) is of importance to development, the requirements of Octopus estimated on this basis appear to be somewhat less in the English Channel than in the Mediterranean. For the English Channel, taking the temperature at spawning as $I I_{2}{ }^{\circ} \mathrm{C}$ and at hatching as $I 4 \frac{1}{2}^{\circ} \mathrm{C}$, with 30 days for development, we obtain a figure of 390 day-degrees. For the Mediterranean, Portmann's figures (Portmann, 1933) give a value of 450 day-degrees, and if it is assumed that the temperature at Naples was between 15 and $20^{\circ} \mathrm{C}$ at the time of his experiments, Naef's figures (Naef, I92I, I923, I928) give values between 420 and 560 day-degrees. It is not considered that these figures conflict unduly with the assumption of at least a month for development in the English Channel.

\section{Temperature and Abundance of Octopus}

For the later stages of the life history of Octopus, we may consider the reports on its abundance in the English Channel at different periods. After about I885 octopus were scarce on both French and English coasts, until in I 899 their numbers assumed plague proportions on the French side, and began to rise appreciably on the English side. In the following year, I900, the octopus were so numerous as to form a nuisance on both sides of the Channel. 
They were noted as plentiful on the Sussex coast in I9I3, I922 and I948, and they were a plague on the Finistère coasts in I922. These latter, except possibly that in I922, may be regarded as more or less minor occurrences, not comparable in magnitude with those of I899 and 1900. In I950 a plague sprang up anew on the French coasts, and the number of octopus began to rise on the English side also during the same year. There were very large numbers of octopus present on both sides of the Channel in I95I, and on the French side in the following year also. Whether they had in fact disappeared from the English coasts in 1952 is not certain. Official records of the size of the octopus population are not kept and the information available cannot be claimed as complete and precise. Accordingly, the absence of reports of octopus in the newspapers, for example, may be due to the animal having lost its news value in 1952 .

In his report on the plague that occurred at the turn of the century, Garstang (I900) suggested that the warm summers and mild winters which, he states, were experienced during the few years preceding the plague provided conditions suitable to a warm-water animal. He remarked further that 'the plague of octopus may be traced to the influence on the reproduction of this species of the exceptionally favourable conditions which prevailed in 1893'. With these points in mind, we may examine the considerable sequence of temperature data now available for the English Channel, in relation to the further records of octopus abundance. Surface observations are representative of the whole column at all seasons in the English Channel, except in the westernmost part. Here a thermocline develops at times during summer, with the result that the upper $30 \mathrm{~m}$ or so of water may be up to $5^{\circ} \mathrm{C}$ warmer than the water below (see Dietrich, I950). The height of 'summer', the season of highest water temperature, falls in July, August or September in the English Channel. Similarly, the depth of 'winter', the season of lowest temperature, occurs in January, February, March or April.

Fig. 3 shows for each year the maximal monthly mean temperature for three districts of the English Channel, at the mouth, in the centre, and towards the Straits of Dover. ${ }^{1}$ The rings immediately below the upper scale of years indicate the years in which the octopus was recorded as notably abundant. We see that, as far as sea temperature is concerned, the summer of 1893 (as judged by the highest monthly mean temperature) was indeed warm, at least in the western part of the Channel, but it was followed immediately by a distinctly cool summer. Thereafter succeeding summers became gradually warmer, culminating in an outstandingly hot one in I899. Turning to the I950 plague, we observe that although the summer of I949 was very hot, in

1 The figures for the western district for the years after I904 are based on the data available for the Regions 5, 8, 9 and ro used by Lumby (1935); for I904 and earlier years they are based on observations at the Seven Stones lightship alone (see E. C. Jee, I919). Similarly, the central district comprises Regions I7, I8, 2I, 22, 23, 24 and 25; and the eastern district, Regions 30, 31, 32, 33, 35, 38 and 40. 


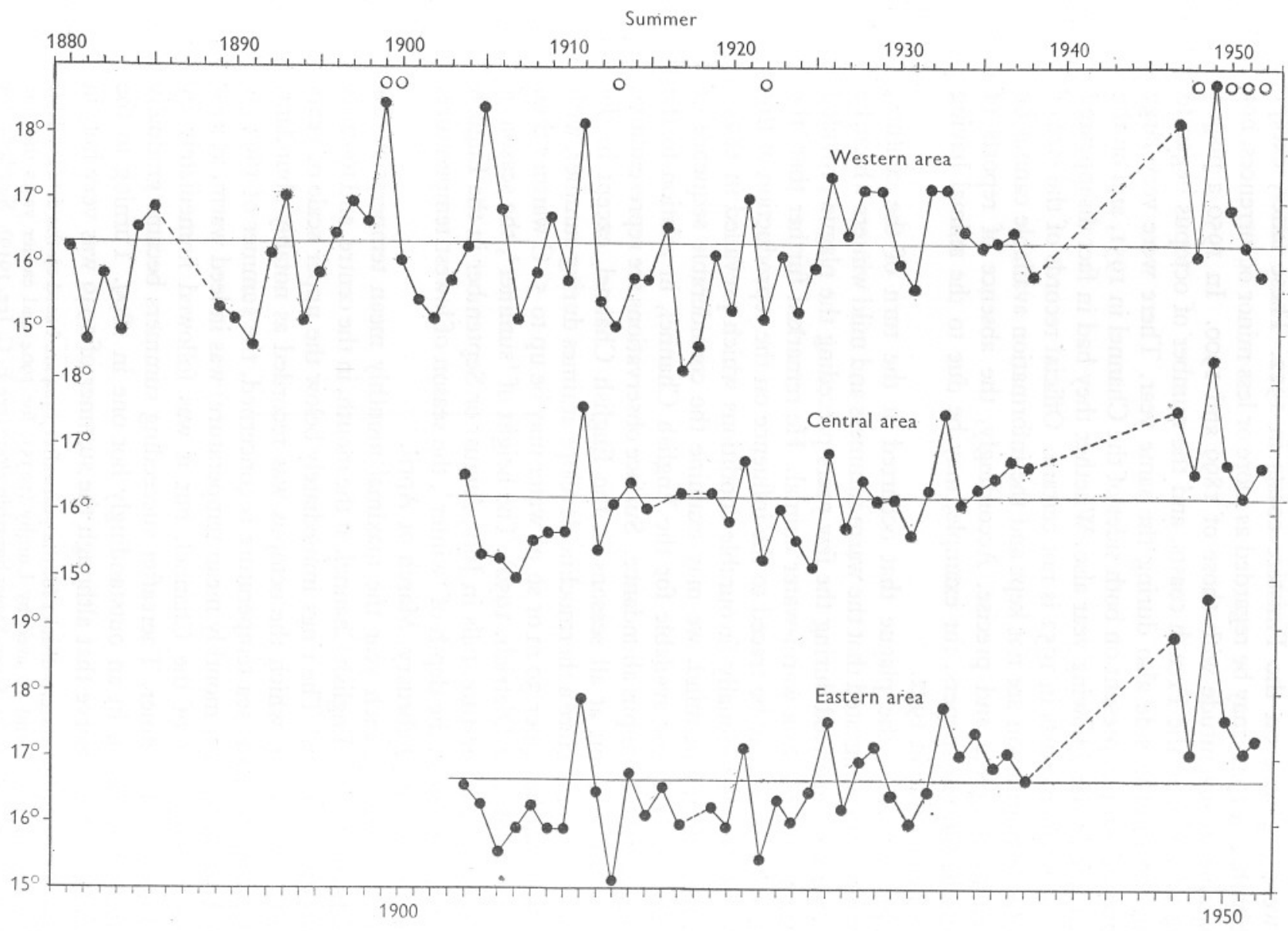

Fig. 3. The maximal monthly mean surface water temperature $\left({ }^{\circ} \mathrm{C}\right)$ for each year in three districts of the English Channel. The western area comprises Regions 5, 8, 9 and Io (see Lumby, 1935); the central area, Regions I7, I8, 21, 22, 23, 24 and 25; and the eastern area, Regions 30, 3I, 32, 33, 35, 38 and 40. For the years before 1905 , the figures for the western area are based on observations at the Seven Stones lightship only. The rings beneath the scale of years indicate years in which Octopus was reported as notably abundant in the English Channel. 


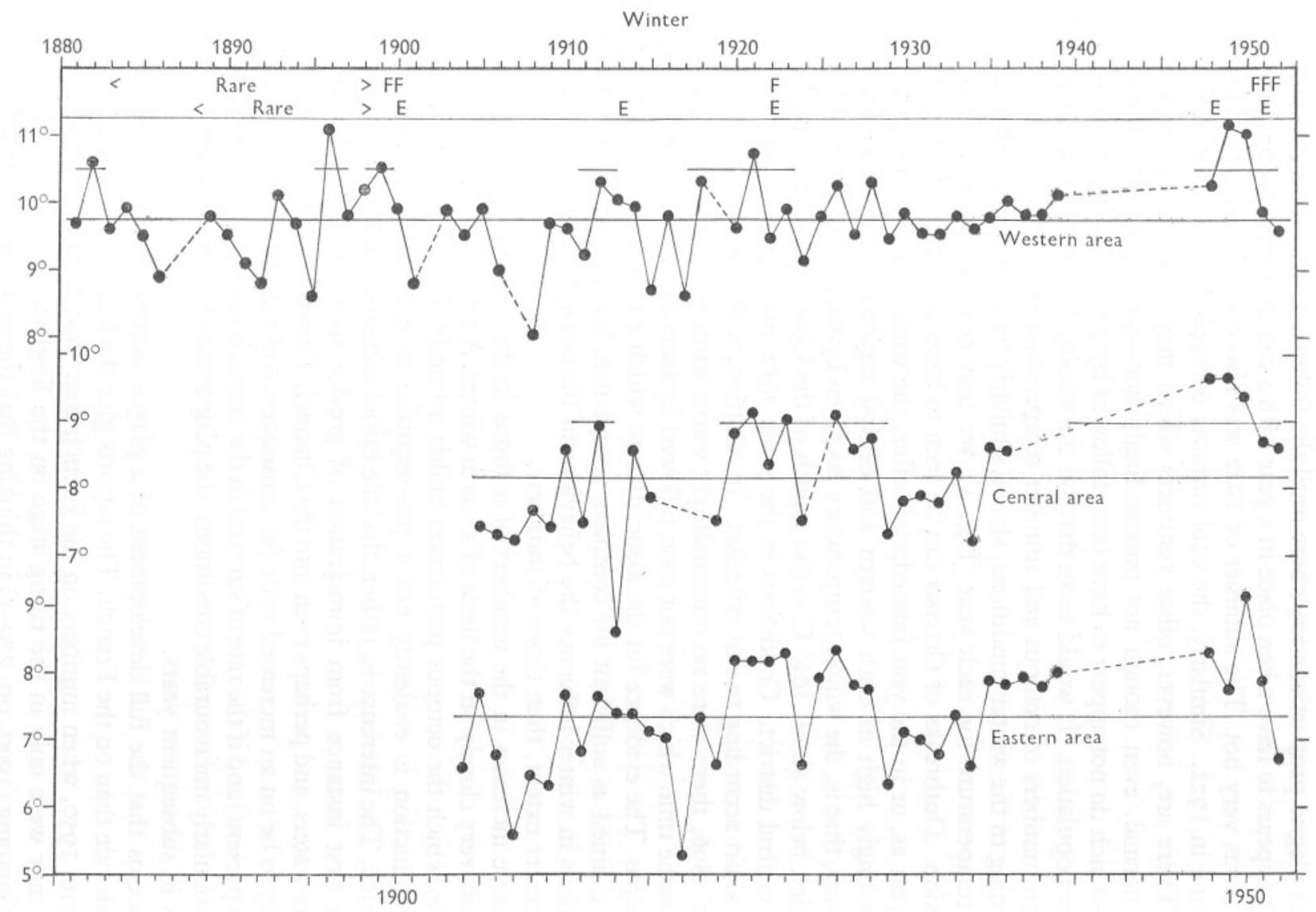

Fig. 4. The minimal monthly mean surface water temperature $\left({ }^{\circ} \mathrm{C}\right)$ for each year in three districts of the English Channel. For details, see legend to Fig. 3. For the western area, the figures for the years before I906 are based on observations at the Seven Stones lightship only. The lettering beneath the scale of years indicates the years in which Octopus was reported as notably abundant on the French coast (F), and on the English coast (E). 
all parts of the Channel, the numbers of octopus do not appear to have reached plague proportions anywhere until the following year. The outbreak in I9I3 appears to have taken place in a year with a cool summer, though that of I9II was very hot. The summer of I922 was also cool, following a fairly warm one in I921. Similarly, the cool summer of 1948 follows a hot one in 1947. There are, however, other summers which may be classified as well above normal, even though not outstandingly hot-for example 1926 and 1933 - which do not appear to have been followed by notable increases in the octopus population. It would seem that, on the whole, the association, if any, between numbers of octopus and summer temperature is not close.

Turning to the winter conditions, shown similarly by the minimal monthly mean temperature for each year (Fig. 4), we may see a somewhat clearer connexion. Outbreaks of Octopus can be seen to have occurred either in the same year as, or in the year immediately after, the winter temperatures were outstandingly high in both western and central regions at the same time; whenever, that is, the winter temperature (as given by the monthly mean) has not fallen below about $10 \frac{1}{2}{ }^{\circ} \mathrm{C}$ at the mouth of the Channel, nor below $9^{\circ} \mathrm{C}$ in the central district. Conditions in the years 1912 and I 948 appear to fall a little short according to this criterion. In addition, with the possible exception of 1896 , there were no outstandingly warm winters in the two regions at the same time which were not soon followed by increases in the abundance of Octopus. The evidence for the association to which attention is drawn here is not claimed as sufficient for complete acceptance, but it seems likely that conditions in winter influence the behaviour of the octopus more directly, or to a greater extent, than those of summer.

Notable increases in the numbers of octopus in the inshore waters appear to follow very closely on the heels of a warm winter. A period of several warm years in which the octopus population builds up under improved conditions of reproduction is evidently not a pre-requisite to a plague, as Garstang suggested. The inference is, rather, that the initial increase in numbers springs in the first instance from immigration of greater numbers of adults into inshore waters, and perhaps even into the Channel. Thereafter, since spawning is likely to be on an increased scale (in consequence of the greater numbers of adults present) and if the rate of survival in the larvae is not unduly diminished by particularly unfavourable conditions, the plague may be intensified by these means in subsequent years.

It seems that the full development of a plague occurs a year later on the English side than on the French. The reports give the impression that in both I899 and 1950, when numbers on the French coast had already become very high, they were only in the rising stage on the English side. We may agree with Garstang (1900, pp. 270-I) in thinking that the explanation for this lies in the pressure of population on the French side becoming so great as to drive the animals to emigrate to the English coasts. It is doubtful whether water 
temperature plays any part in this, since, although the summer of 1899 was exceedingly hot, that of 1950 was only slightly in excess of the average. In 1949, when the summer temperature was even higher than in I899, the plague had not yet developed on the French side, so far as the records show.

\section{Lowest Tolerable Temperature and Migration}

As a rule the octopus appear to move away from the inshore regions when the height of summer has passed, and to spend the winter in the deeper waters offshore. After the winter, they return inshore for spawning. There is some slight indication that shoreward movement is discouraged by very severe winters, not only in the spring immediately following, but for a period of a year or more. The severity of the winter of 1895 , for instance, may account for the absence of an outbreak of Octopus after the very mild winter of 1896 . The winter of 1947 was extremely cold; the monthly mean temperature for February 1947 was $4.8^{\circ} \mathrm{C}$ at Jersey and $4.9^{\circ} \mathrm{C}$ off Plymouth. This may have delayed the outbreak of the plague, perhaps, but the evidence for this point is too indefinite to allow reliable conclusions to be drawn.

On the other hand, in some years octopus are known to remain inshore throughout the winter. An occasional juvenile octopus was caught off Plymouth by the research vessels of the Marine Biological Association in March I950, and throughout the following winter (195I) Octopus were being caught by the Sabella within I6 miles of Plymouth Breakwater (see Appendix). During March I950 the sea temperature near Plymouth Breakwater (Station L. 2) was between 9 and $10^{\circ} \mathrm{C}$, and about $\frac{1}{2}^{\circ} \mathrm{C}$ higher near the Eddystone (St. E. I). In winter I95I the sea temperature at St. L. 2 fell to $8^{\circ} \mathrm{C}$, possibly a little below, and to about $8 \frac{1}{2}^{\circ} \mathrm{C}$ near the Eddystone during this period. The average winter temperature-the monthly mean for February-in Region II (see Lumby, 1935) is estimated at $8.7^{\circ} \mathrm{C}$ for the period $1903-27$ and $8.2^{\circ} \mathrm{C}$ for the period I928-5I (these latter figures are not yet published). On the other side of the Channel, as Mr Baal informs us, Octopus remained inshore at Jersey during three successive winters, those of I950, I95I and I952. They did not leave these waters until October I952. The lowest monthly mean temperatures in these waters were $8 \frac{1}{2}^{\circ}, 6^{\circ}$ and $7 \frac{1}{2}^{\circ} \mathrm{C}$, for these three winters respectively. These compare with an average value of $7^{\circ} \mathrm{C}$ over the years I933-39, I946-52. In October I952, when the animal left these waters, the average temperature was $13 \frac{1}{2}^{\circ} \mathrm{C}$; in November, $10 \frac{1}{2}^{\circ} \mathrm{C}$.

From this we may conclude with assurance that Octopus tolerates temperatures as low as $6^{\circ} \mathrm{C}$. However, in view of the fact that this value is well below the average winter temperature of the water both off Plymouth and at Jersey, and since the animal is not normally present in these waters in winter, it must be concluded that the occurrence of Octopus at this season is governed by temperature only to quite a limited extent. It is clearly not true that the animal may always be expected to be present when the water temperature is 
above $6^{\circ} \mathrm{C}$, and there is thus no justification for inferring from the absence of Octopus from waters of a certain temperature that the animal is intolerant of that temperature. We therefore cannot yet determine from the evidence before us, what is the lowest temperature Octopus can tolerate; for a warmwater animal, however, it is evidently surprisingly low.

At the mouth of the English Channel the lowest monthly mean temperature recorded, that of $\mathrm{I908}$, was just above $8^{\circ} \mathrm{C}$ (Fig. 4). Thus only very infrequently indeed would the octopus find a water temperature below $6^{\circ} \mathrm{C}$ in this part of the English Channel. Moreover, as the chart of average winter

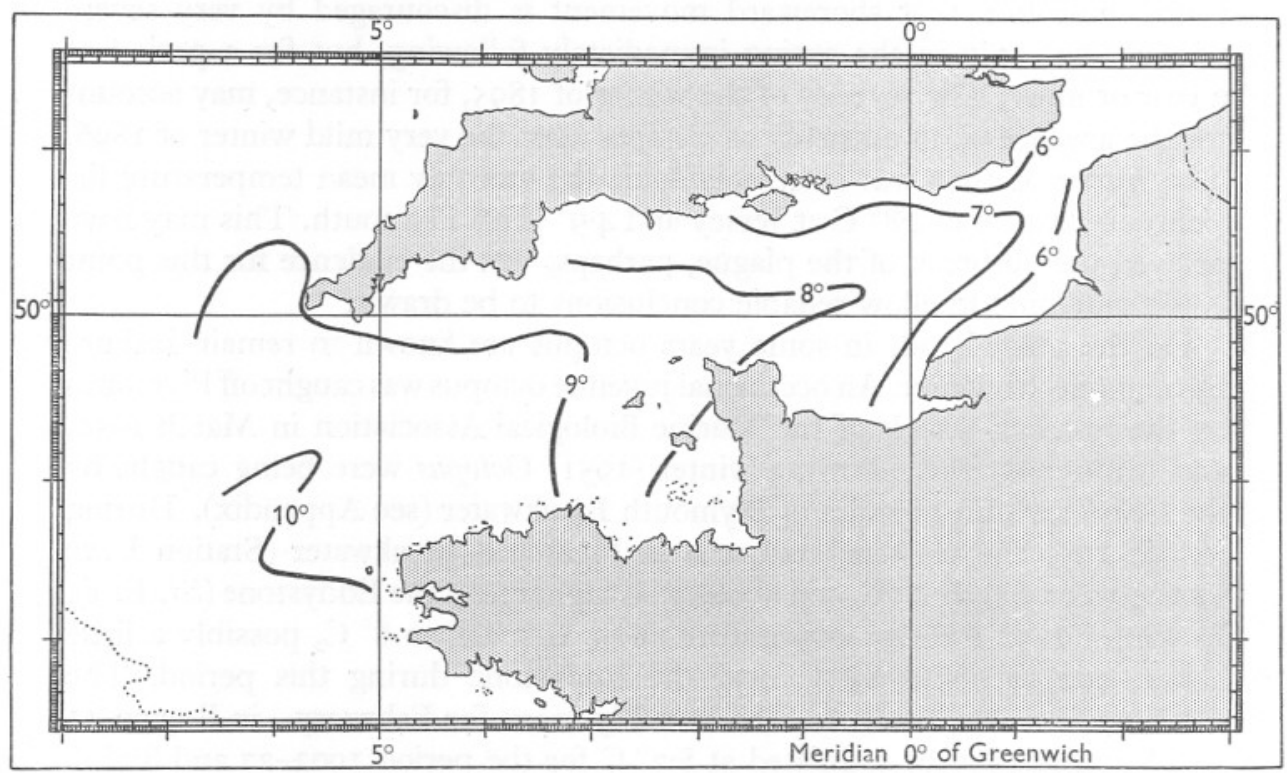

Fig. 5. The minimal monthly mean temperature $\left({ }^{\circ} \mathrm{C}\right)$ of the surface water in the English Channel, based on observations over the period 1903-27.

temperature shows (Fig. 5), the octopus can find, on the average, water of a tolerable temperature almost everywhere in the English Channel. In view of this, and also of the apparent ability of the animal to increase its numbers inshore very quickly after a warm winter, it would not be surprising to find that there is almost always quite a large population of Octopus inhabiting the Channel, which is not noticed except in some special seasons.

\section{DisCUSSION}

The disturbances caused by the abundance of Octopus in 1950-5I followed the same general pattern as in 1899-1900. Recently, as in the earlier 'plague', shell-fishing had to be temporarily abandoned at some points on the Devon coast and on the French coast. In so far as it has been possible to get authentic 
records for 1950-5I, most of the octopus were of medium size with an arm span of $2 \frac{1}{2}-3 \mathrm{ft}$., but specimens reaching $5-5 \frac{1}{2} \mathrm{ft}$. were reported. They were therefore smaller on the average than those mentioned by Garstang (I900).

We believe that the distribution of larvae shown in Fig. I gives conclusive evidence that the main breeding grounds of Octopus in the south-western Channel are in coastal waters, from Ushant eastwards along the north coast of France, and around the Channel Islands, to as far east as the neighbourhood of Grandcamp-les-Bains. Occasional spawning on the English side appears to be insufficiently frequent to be represented in the catches.

We have not been able to add much to greatly needed information on the growth of this species. It appears, however, that larvae hatched the previous year reach a size at least $\mathrm{I} 4 \mathrm{~mm}$ in mantle length by March of the following year (see p. 5I5). This particular specimen may have hatched very late in the breeding season and may have lived through the winter without much growth. In size it may be comparable with young octopus of very small size reported by Devon fishermen in the autumn of 1950. From scattered reports received from the whole south coast most of the octopus seen in July and August I950 were about $2 \frac{1}{2} \mathrm{ft}$. in arm span, and, on this point, we think it extremely likely that they were not more than two years old, and although we have no evidence on this point, some may have been only just over a year old.

During the recent years of numerical abundance of Octopus this species has been present in inshore waters the whole year round on the English coast and in the Channel Islands. Even in Jersey, as Mr H. J. Baal informs us (in litt.), in normal years Octopus disappears from inshore waters in winter but since the winter of I949-50 it has been quite common throughout the period but disappeared into deeper water in October I952 (Baal, I953). Sinel (1906, p. 215) implies that it is present only in summer at Jersey in normal years in the words: 'it is constant during the summer months'. In another paragraph (p. 222) dealing with the capture of Octopus, he indicates his belief in a southerly migration of Octopus in the autumn: "Yet another plan, much used in the autumn on the north coast of Jersey: in this particular locality, and at this time, they sometimes swarm on the sea surface, swimming in the method last described, no doubt to some more congenial shore. Men armed with long bamboo rods, with large hooks at the end, station themselves on outlying rocks, and simply hook them out as they pass. I have seen many tons' weight caught in one locality by this method, and being used to manure the land.' Mr Baal also informs us that he has seen this southerly movement at this place in the autumn but there is as yet no real evidence of large-scale migratory movement other than the migration across the Channel in plague years and seasonal retreat into deeper water (see p. 516). In Eledone these seasonal movements, from offshore fishing grounds to inshore waters, which take place in the summer, followed by a retreat to deeper water in winter, have been reported by Isgrove (1909). Eledone cirrhosa is much rarer on the 
south side of the Channel than in English waters, but after the octopus became more abundant, Eledone became scarcer, presumably because it is eaten by the larger species.

The virtual disappearance of the lobster (Homarus vulgaris) on offshore fishing grounds with the arrival of Octopus (see Appendix I) was to be expected. The increase in numbers of crawfish (Palinurus vulgaris) on the trawling grounds implies that they were being driven out of their usual haunts to areas where Octopus was less abundant. There is no information available to suggest that the spider crab (Maia squinado) was being driven ashore on the English coast as in 1899-1900. Baal (1953), however, notes that in the autumn of 1952 spider crabs were numerous in shallow lagoons exposed at spring tides in Jersey. He observed that 'the spider crabs had collected into large heaps, about two feet and three feet in diameter, with their legs so entangled as to make it difficult to separate a crab from the heap. The octopuses captured some from the outside of the masses but the greater number survived, and day after day the heaps remained.' As Baal implies, this curious behaviour may have a survival value for the spider crab.

We wish to thank the Director of Fishery Investigations, Lowestoft, for readily placing the plankton samples of the Sir Lancelot cruises at our disposal. We are also greatly indebted to $\mathrm{Mr} \mathrm{H}$. J. Baal, Lieut.-Commander W. H. Batten, Lieut.-Commander C. A. Hoodless, D.S.C., and Prof. J. Z. Young, F.R.S., for information on local abundance of octopus.

Thanks are also due to Dr H. W. Parker (for larvae collected by him off the Casquets in I950), Mr F. S. Russell, F.R.S. (for a juvenile octopus from Plymouth), and Alderman W. P. D. Stebbing for an adult octopus from Deal.

\section{SUMMARY}

The great abundance of Octopus vulgaris on the English coast of the Channel in I950-5I recalls the previous 'plague' in I899-I900 when, as now, Devon and Cornwall seemed affected the most.

It has been possible to demonstrate from plankton surveys of the Channel in I948, I949 and I950 that planktonic larvae of Octopus originate on the south side of the Channel in the area between the Cotentin peninsula, the Channel Islands, and Ushant (Fig. I). There is no indication of substantial breeding on the English coast.

Spawning commences in May in the extreme south-west, but the main spawning occurs in June and July, larvae becoming numerous in July and August. Larvae still planktonic in September are in process of dispersal to the north and east. The water temperature when spawning begins is estimated to be about $\operatorname{II} \frac{1}{2}-12^{\circ} \mathrm{C}$.

Apart from a suggestion that mild winter conditions encourage the species 
to become very abundant almost immediately on the French coast, Octopus appears to be influenced very little by sea temperature. Dearth of food seems to be the cause of subsequent trans-Channel migration of adults. From the evidence available Octopus tolerates temperatures as low as. $6^{\circ} \mathrm{C}$.

\title{
REFERENCES
}

BAAL, H. J., I953. Behaviour of spider crabs in the presence of octopuses. Nature, Lond., Vol. I7I, p. 887.

Dietrich, G., I950. Die natürlichen Regionen von Nord- und Ostsee auf hydrographischer Grundlage. Kieler Meeresforsch., Bd. 7, pp. 35-69.

Garstang, W., I900. The plague of Octopus on the South Coast and its effect on the crab and lobster fisheries. F. Mar. biol. Ass. U.K., Vol. 6, pp. 260-73.

Guiart, L., 1900. Les méfaits du poulpe (Octopus vulgaris) en Bretagne. Bull. Soc. zool. Fr., T. 24, pp. I18-20.

Isgrove, A., 1909. Eledone. Liverpool Mar. biol. Comm. Memoir, No. I8.

JeE, E. C., I9I9. Hydrographic observations at the Seven Stones Lightship. Fish Invest., Lond., Ser. III, Vol. 2, pt. I.

Lumby, J. R., I935. Salinity and temperature of the English Channel. Fish. Invest., Lond., Ser. II, Vol. I4, pt. 3 (with separate Atlas of Charts).

NaEF, A., I921, I923, I928. Die Cephalopoden. Fauna e Flora del Golfo di Napoli, Monogr. 35, Parts I-III.

Pontmann, A., I933. Observations sur la vie embryonnaire de la pieuvre (Octopus vulgaris Lam.). Arch. Zool. exp. gén., T. 76, pp. 24-35.

REES, W. J., 1950. The distribution of Octopus vulgaris Lamarck in British waters. 7. Mar. biol. Ass. U.K., Vol. 29, pp. 26I-378.

- I952. Octopuses in the Channel. New Biology, Vol. I2, pp. 58-67.

- 1953. The Octopus larvae of the Thor. Proc. malac. Soc. Lond., Vol. 29, pp. 215-18.

SineL, J., I906. An outline of the natural history of our shores. London: Swan Sonnenschein and Co.

TAIT, J. B., I95I. On the application to marine research of the meteorological concept of accumulated temperature. F. Cons. int. Explor. Mer, Vol. I7, No. 2.

\section{APPENDIX I}

\author{
By Lieut.-Commander C. A. HoodLESS, D.S.C., R.N.R., \\ Master, R.V. Sabella
}

Records of Octopus vulgaris and Eledone cirrhosa trawled off Plymouth between I June 1948 and 30 June I95I by R.V. Sabella

All the trawl hauls were made within a I6-mile radius of Plymouth Breakwater with a standard otter trawl with a head line of $56 \mathrm{ft}$.

I948. In the 7 months of this year covered by the record 2 Eledone were taken, both in October.

1949. I Eledone taken in October. 
1950. Up to the commencement of the accompanying table single specimens of Eledone were taken in January, July and August.

During the whole of the above periods Sabella was making an average of II trawl hauls a month.

The first record of Octopus was on 4 September I950. From that date Homarus vulgaris almost completely disappeared from the trawling grounds but Palinurus vulgaris was taken in much larger numbers than before.

The table below shows the numbers of Octopus and Eledone taken between September I950 and June I95I, with the number of trawl hauls and the average number of specimens per haul:

\begin{tabular}{|c|c|c|c|c|c|}
\hline \multirow[b]{2}{*}{ Month } & \multirow[b]{2}{*}{$\begin{array}{l}\text { No. of } \\
\text { trawl hauls }\end{array}$} & \multicolumn{2}{|c|}{ Eledone cirrhosa } & \multicolumn{2}{|c|}{ Octopus vulgaris } \\
\hline & & $\begin{array}{l}\text { No. of } \\
\text { specimens }\end{array}$ & $\begin{array}{l}\text { Average } \\
\text { per haul }\end{array}$ & $\begin{array}{l}\text { No. of } \\
\text { specimens }\end{array}$ & $\begin{array}{l}\text { Average } \\
\text { per haul }\end{array}$ \\
\hline September I950 & 20 & I & 0.05 & 2 & O.I \\
\hline October & 15 & - & - & 3 & 0.2 \\
\hline November & 16 & 一 & - & 2 & $0 . I$ \\
\hline December & 9 & 一 & - & 9 & $I \cdot O$ \\
\hline January I95I & I3 & 3 & 0.2 & 3 & 0.2 \\
\hline February & I3 & - & - & 29 & $2 \cdot 2$ \\
\hline March & 3 & 一 & - & 4 & $I \cdot 3$ \\
\hline April & I6 & I & 0.1 & I3 & 0.8 \\
\hline May & 20 & - & - & I 7 & 0.9 \\
\hline June & I0 & - & - & 2 & 0.2 \\
\hline
\end{tabular}

